\title{
ASSESSMENT OF PERIOPERATIVE PROPHYLAXIS OF INFECTIOUS COMPLICATIONS IN POST-OP PATIENTS
}

Morozova TE, Lukina MV $\bowtie$, Andrushishina TB, Chukina MA

Department of Clinical Pharmacology and Propedeutics of Internal Diseases, Faculty of General Medicine,

I.M. Sechenov First Moscow State Medical University, Moscow

\begin{abstract}
Perioperative antimicrobial prophylaxis (PAP) involves administration of antimicrobial agents (AMA) to patients undergoing a surgical intervention and aims to reduce the risk of postoperative infectious complications, especially at surgical sites. In the present work we assess efficiency and safety of AMA used for prevention of postoperative infectious complications. In the course of our study we pre-analyzed 576 medical histories of post-op patients aged 18 to 87 years (mean age M \pm SD was $57.4 \pm 14.5$ years), of which 347 (60.2\%) were male and 229 (39.8\%) female. Only 481 histories were selected for final analysis. We assessed the choice of antibacterial therapy, the frequency of adverse reactions (AR) and infectious complications and the type of the latter. PAP regimens were consistent with the official guidelines in 207 (43.04\%) cases. PAP recommendations were ignored in 274 cases (56.96\%), and the timing was wrong in 364 cases (75.7\%). Incorrect dosages were administered in 225 cases (46.8\%). We also discovered an association between irrational PAP regimens and 1) the length of patient's stay in the intensive care unit $(p=0.003$ and $p<0.005), 2)$ the frequency of reoperations associated with infection $(p=0.001), 3)$ mortality rates $(p=0.002)$, and 4$)$ isolation of strains with multidrug resistance $(p=0.016)$. We conclude that PAP regimens for the inpatients of surgical wards are often compromised by failure to comply with the official guidelines, wrong timing and incorrect dosage, which negatively affects hospital statistics.
\end{abstract}

Keywords: antibacterial agents, perioperative antimicrobial prophylaxis, infectious complications, surgery, efficiency, adverse reactions

Acknowledgements: the authors thank Oleg Babenko of Clinical Hospital No.1 of I.M. Sechenov First Moscow State Medical University for granting access to Hospital's archived medical records.

Correspondence should be addressed: Maria Lukina

Bolshaya Pirogovskaya 2, str. 4, k. 106, Moscow, 119435; mari-luk2010@yandex.ru

Received: 29.12.2017 Accepted: 23.03.2018

DOI: $10.24075 / \mathrm{brsmu} .2018 .012$

\section{ОЦЕНКА РАЦИОНАЛЬНОСТИ ПРОВЕДЕНИЯ ПЕРИОПЕРАЦИОННОЙ АНТИМИКРОБНОЙ ПРОФИЛАКТИКИ ИНФЕКЦИОННЫХ ОСЛОЖНЕНИЙ У ПАЦИЕНТОВ ПОСЛЕ ХИРУРГИЧЕСКИХ ВМЕШАТЕЛЬСТВ}

\author{
Т. Е. Морозова, М. В. Лукина ${ }^{凶}$, Т. Б. Андрущишина, М. А. Чукина
}

Кафедра клинической фармакологии и пропедевтики внутренних болезней, лечебный факультет,

Первый Московский государственный медицинский университет имени И. М. Сеченова (Сеченовский Университет), Москва

Назначение антибактериальных препаратов (АБП) для проведения периоперационной антимикробной профилактики (ПАП) пациентам хирургического профиля необходимо для снижения частоты возникновения инфекционных осложнений в послеоперационном периоде, в том числе инфекций области хирургических вмешательств. Целью работы была оценка рациональности и безопасности выбора АБП для проведения ПАП инфекционных осложнений у пациентов после хирургических вмешательств. Проведен фармакоэпидемиологический анализ 576 историй болезней пациентов в возрасте от 18 до 87 лет после хирургических вмешательств, средний возраст (M \pm SD) составил 57,4 土 14,5 года, мужчин - 347 (60,2\%), женщин - 229 (39,8\%). В финальный анализ рациональности схем ПАП вошли 481 история болезни. Оценивали рациональность выбора антибактериальной терапии, частоту развития неблагоприятных побочных реакций (НПР), частоту и характер инфекционных осложнений. Показано, что выбор схем ПАП соответствовал рекомендациям в 207 (43,04\%) случаях. Выявлена высокая частота несоблюдения рекомендаций по проведению ПАП (274; 56,96\%) и нарушения сроков проведения ПАП (364; 75,7\%). Общее число случаев нарушения режимов дозирования составило 225 (46,8\%). Обнаружена взаимосвязь нерациональных схем ПАП с длительностью пребывания в ОРИТ ( $p=0,003$ и p < 0,005), частотой повторных оперативных вмешательств, ассоциированных с инфекцией ( $p=0,001)$, уровнем летальности $(p=0,002)$ и выделением полирезистентных штаммов $(p=0,016)$. Таким образом, у пациентов хирургического профиля в условиях реальной клинической практики сохраняется высокая частота несоблюдения рекомендаций по проведению ПАП, нарушения сроков проведения ПАП и режимов дозирования АБП, что негативно сказывается на госпитальных показателях.

Ключевые слова: антибактериальные препараты, периоперационная антимикробная профилактика инфекционных осложнений хирургического вмешательства, рациональность применения, неблагоприятные побочные реакции

Благодарности: авторы благодарят Бабенко Олега Васильевича из УКБ № 1 Первого МГМУ им. И. М. Сеченова за возможность доступа к архиву историй болезней.

$\checkmark$ Для корреспонденции: Лукина Мария Владимировна

ул. Большая Пироговская, д. 2, стр. 4, каб. 106, г. Москва, 119435; mari-luk2010@yandex.ru

Статья получена: 29.12.2017 Статья принята к печати: 23.03.2018

DOI: 10.24075/vrgmu.2018.012 
Perioperative antimicrobial prophylaxis (PAP) is an internationally accepted standard of care for surgical patients. It involves the use of antibacterial agents (AA) and aims at lowering the risk of infectious complications in general and surgical site infections (SSI) in particular. Any postoperative infectious complication negatively affects the outcome of surgery, extends a patient's stay in hospital, incurs high costs, increases the risk of resurgeries, contributes to hospital death rates and requires additional drug-based therapy [1].

According to the European Center for Disease Prevention and Control (ECDC) and the World Health Organization (WHO), infectious complications associated with multi-drug resistant and pan-resistant strains have recently become alarmingly incident [2, 3].

Among the factors promoting antibiotic resistance are overuse and misuse of AA [4]. In this light, a wise approach to the choice of antibacterial therapy becomes particularly important [5]. Inappropriate dosing, including administration of subtherapeutic doses of AA both for treatment and prevention, and prolonged post-operative prophylaxis ( $>24 \mathrm{~h}$ ) reduce PAP efficacy and contribute to antimicrobial resistance [6, 7].

The Russian Federation actively supports measures for curbing antibiotic resistance. Revised clinical recommendations proposed in the National Strategy for Antimicrobial Treatment Control highlight the necessity of control over the spread of nosocomial infections [8]. Systemic monitoring of antibiotic resistance and trade regulations are essential components of this strategy [9].

Therefore, the rational use of $A A$ in the clinical setting becomes an important tool for reducing the risk of SSI and adverse reactions (AR) and curbing antibiotic resistance.

The aim of this study was to assess the choice of AA with regard to its adequacy and safety in patients undergoing PAP.

\section{METHODS}

We have analyzed the regimens of antimicrobial PAP given to the inpatients of surgical units with regard to their adequacy and compliance with national and international clinical guidelines [1, 10]. We set up a database containing details of patients' clinical and demographic profiles (sex, age, diagnosis, comorbidities, creatinine levels, creatinine clearance rates before and after surgery) and surgical interventions, including blood loss volume, wound contamination, complications, adverse reactions, and AA doses).

A total of 576 medical histories were selected for the analysis. Of all patients included in the preliminary analysis, 347 (60.2\%) were men and 229 (39.8\%) - women. Their age ranged from 18 to 87 years (mean age $\mathrm{M} \pm \mathrm{SD}$ was $7.4 \pm 14.5$ years). All of the patients had undergone a surgical intervention between June 2016 and December 2016. Details are presented in Table 1.

All surgical interventions performed on the analyzed patients were divided in three groups: general surgeries (356; 61.8\%), cardiac surgeries $(177 ; 30.7 \%)$, and cancer surgeries (21; $3.6 \%)$. The majority of the surgical interventions were elective (468; $81.3 \%)$. Most of the surgical wounds were clean (310; $53.8 \%)$. Infected wounds were observed in 113 (19.6\%) patients who had septic suppurative inflammation at various locations. Clean-contaminated and contaminated wounds were observed in 70 (12.2\%) and 84 (14.6\%) patients, respectively.

Only 481 medical histories were selected for the final analysis. The rest 95 (16.5\%) were excluded due to the lack of reliable data about PAP.

PAP adequacy and safety were assessed based on:

- AA regimens;

- adequacy of regimens, timing and duration of PAP;

- frequency of adverse reactions.

The total frequency of post-operative infectious complications and SSI were also estimated.

In addition, we have analyzed the impact of different factors, such as PAP regimens, clinical and demographic characteristics of patients (age, sex, BMl, underlying medical condition, renal function, type of surgery, wound contamination, blood loss volume) on the risk of infectious complications, the length of hospital stay, the length of stay in intensive care and death.

Statistical analysis was performed in STATISTICA 10.0 (StatSoft Inc., USA). The data were presented as means (M) and the standard deviation (SD). Normality of sample distribution was evaluated by the Shapiro-Wilk W test; homogeneity of variances across two samples was tested using Fisher's T-test. The differences were considered significant at $p<0.05$. Apart from the correlation analysis, we also used the Mann-Whitney $\mathrm{U}$ and Kolmogorov-Smirnov tests to compare two independent

Table 1. Clinical characteristics of patients included in the analysis

\begin{tabular}{|c|c|c|c|c|c|c|}
\hline \multirow[t]{2}{*}{ Parameter } & \multirow{2}{*}{$\begin{array}{l}\text { Patients } \\
\mathrm{n}=576 \\
\mathrm{M} \pm \mathrm{SD}\end{array}$} & \multicolumn{2}{|c|}{$\begin{array}{c}\text { Male } \\
\mathrm{n}=347\end{array}$} & \multicolumn{2}{|c|}{$\begin{array}{l}\text { Female } \\
n=229\end{array}$} & \multirow[t]{2}{*}{$p$} \\
\hline & & M & SD & M & SD & \\
\hline Age. years & $57.4 \pm 14.5$ & 57.8 & 13.6 & 56.9 & 15.6 & 0.468 \\
\hline BMI. $\mathrm{kg} / \mathrm{m}^{2}$ & $28.20 \pm 5.67$ & 27.70 & 4.80 & 29.01 & 6.80 & 0.005 \\
\hline Hospital stay. days & $18.10 \pm 22.05$ & 17.20 & 10.70 & 19.60 & 32.40 & 0.197 \\
\hline Onset of infectious complications. days after surgery & $1.5 \pm 3.6$ & 1.1 & 3.6 & 1.3 & 3.7 & 0.596 \\
\hline Onset of non-infectious complications. days after surgery & $0.89 \pm 4.39$ & 0.88 & 2.70 & 0.90 & 6.20 & 0.942 \\
\hline Re-operation. days after initial surgery & $1.18 \pm 3.96$ & 1.40 & 4.30 & 0.85 & 3.30 & 0.114 \\
\hline Length of stay in intensive care. days & $3.10 \pm 7.60$ & 2.76 & 6.20 & 3.63 & 9.20 & 0.180 \\
\hline Duration of mechanical ventilation. days & $0.61 \pm 4.12$ & 0.30 & 2.67 & 1.04 & 5.60 & 0.041 \\
\hline Blood loss. ml & $214.1 \pm 483.1$ & 169.9 & 426.7 & 243.3 & 515.5 & 0.074 \\
\hline Creatinine $^{0 \star} . \mathrm{mg} / \mathrm{dl}$ & $0.95 \pm 0.49$ & 1.05 & 0.56 & 0.83 & 0.32 & $<0.0001$ \\
\hline Creatinine $^{1 * \star} \cdot \mathrm{mg} / \mathrm{dl}$ & $1.07 \pm 0.94$ & 1.13 & 0.76 & 0.98 & 1.16 & 0.058 \\
\hline Creatinine $^{0 *}$ clearance rate. $\mathrm{ml} / \mathrm{min}$ & $96.80 \pm 42.50$ & 100.61 & 44.91 & 91.17 & 38.01 & 0.009 \\
\hline Creatinine $^{1 * \star}$ clearance rate. $\mathrm{ml} / \mathrm{min}$ & $74.79 \pm 52.20$ & 76.32 & 48.79 & 72.48 & 57.03 & 0.401 \\
\hline
\end{tabular}

Note: * — creatinine levels and clearance rates (Cockcroft-Gault equation) before surgery; ** — creatinine levels and clearance rates (Cockcroft-Gault equation) 24-48 $\mathrm{h}$ after surgery 
continuous variables not complying with normal distribution. Two qualitative independent variables were compared using the two-tailed Fisher's test or $\chi^{2}$ with Yates' correction.

\section{RESULTS}

The retrospective analysis of medical histories of 481 patients has revealed that in 297 (43.04\%) cases the choice of antibiotics was rational and consistent with existing clinical guidelines. In 274 (56.96\%) cases the choice of AA was not rational because it did not account for wound contamination and the specifics of surgery. On the whole, PAP regimens were characterized by the frequent use of $3^{\text {rd }}$ generation cephalosporins $(\mathrm{CPh})$ and cycling of $1^{\text {st }}, 2^{\text {nd }}, 3^{\text {rd }}$ and $4^{\text {th }}$ generations of $\mathrm{CPh}$ in preand postoperative management; the regimens also included carbapenems and inhibitor-protected aminopenicillins in combination with aminoglycosides (amikacin), metronidazole, and fluoroquinolones (ciprofloxacin), which were administered to the patients with clean and clean-contaminated wounds. In the studied patients' sample wrong PAP timing was observed in 364 (75.7\%) cases. Inappropriate dosing was noticed in 225 $(46.8 \%)$ cases.

Good choice of PAP regimens (207; 43.04\%) was spoiled by inappropriate AA doses in 64 (30.9\%) cases (Table 2).

In $364(75.7 \%)$ cases, the inadequate choice of AA (274; $56.96 \%$ ) was accompanied by prolonged PAP (regimens were extended beyond 24-48 hours); subtherapeutic doses were prescribed in 161 (58.8\%) cases (Tables 2, 3).

\section{Analysis of safety of antibacterial agents used for perioperative prophylaxis}

The retrospective analysis of medical records revealed that the total number of adverse reactions was 23 (3.99\%); all of them were observed in the group of patients who received prolonged PAP. No adverse reactions were observed in the group of patients who received PAP before surgery and in the group where PAP regimens were limited to 48 hours. Thus, the risk of adverse reactions increases with PAP duration (Table 4).

Retrospectively, the following AR were observed:

- antibiotic-associated colitis - 9 cases (39.1\%);

- psychomotor agitation - 6 cases (26.1\%);

- pseudoallergies - 3 cases (13.0\%);

- elevated transaminases - 3 cases (13.0\%);

- antibiotic-induced nephropathy (vancomycin) -2 cases (8.6\%);

- prolonged QT interval - 2 cases (8.6\%).

Further analysis revealed positive correlations between the risk of adverse reactions and: age $(r=0.109 ; p=0.009)$, the length of hospital stay $(r=0.291 ; p<0.0001)$, the length of stay in the intensive care unit $(r=0.374 ; p<0.0001)$, death $(r=0.269 ; p<0.0001)$, incidence of non-infectious postoperative complications ( $r=0.340 ; p<0.0001)$, postoperative creatinine levels and creatinine clearance rates $(r=0.256$; $p<0.0001)$. No correlations were found between $A R$ and: allergies $(r=0.039 ; p=0.348)$, the choice of PAP regimens $(r=0.340$; $p=0.387)$, dosing $(r=0.028 ; p=0.504)$, PAP duration $(r=0.017 ; p=0.687)$ and infectious complications $(r=0.032$; $\mathrm{p}=0.443)$.

The Mann-Whitney and Kolmogorov-Smirnov tests confirmed the presence of reliable associations between AR and age, the length of hospital stay, the length of stay in the intensive care unit, duration of mechanical ventilation and postoperative complications. However, the KolmogorovSmirnov test did not yield significant values for death ( $p=0.121$, Table 5). Importantly, low creatinine clearance rates in postoperative patients receiving antibiotics were a significant predictor of AR development.

Table 2. Antibacterial agents used in perioperative prophylaxis and inappropriate dosing

\begin{tabular}{|c|c|c|}
\hline PAP regimen & Number of regimens, $\mathrm{n}$ & Inappropriate dosing, $\mathrm{n}$ \\
\hline 1. Adequate PAP regimens & 207 & 64 \\
\hline $1^{\text {st }}$ and $2^{\text {nd }}$ generation cephalosporins & 93 & 29 \\
\hline $1^{\text {st }}$ generation cephalosporin + metronidazole & 27 & 24 \\
\hline Inhibitor-protected aminopenicillins & 87 & 11 \\
\hline 2. Inadequate PAP regimens & 274 & 161 \\
\hline $3^{\text {rd }}$ and $4^{\text {th }}$ generation cephalosporins & 141 & 68 \\
\hline $3^{\text {rd }}$ and $4^{\text {th }}$ generation cephalosporins + metronidazole & 72 & 56 \\
\hline Cycling of $1^{\text {st }}, 2^{\text {nd }}$ and $3^{\text {rd }}$ generation cephalosporins & 39 & 23 \\
\hline Cycling of cephalosporins and vancomycin & 11 & 8 \\
\hline Carbapenems & 7 & 2 \\
\hline Inhibitor-protected aminopenicillins in combination with aminoglycosides or fluoroquinolones & 4 & 4 \\
\hline
\end{tabular}

Table 3. Duration of perioperative prophylaxis

\begin{tabular}{|l|c|c|}
\hline \multirow{2}{*}{ PAP timing } & \multicolumn{2}{|c}{ Number of patients } \\
\cline { 2 - 3 } & abs. & 217 \\
\hline Administration of a single AA dose before surgery & 364 & 75.6 \\
\hline Inadequate duration of PAP: & 92 & 25.3 \\
\hline PAP extended to $24 \mathrm{~h}$ & 71 & 19.5 \\
\hline PAP extended to 48 $\mathrm{h}$ & 100 & 27.5 \\
\hline 3-4 days & 63 & 17.3 \\
\hline 5-7 days & 26 & \\
\hline $8-10$ days & 12 & 7.1 \\
\hline $11-14$ days & & 3.3 \\
\hline
\end{tabular}




\section{Frequency of infectious complications in the postoperative period}

Postoperative infectious complications were observed in 90 (15.6\%) cases, dominated by SSI (45; 50\%) and infections of the lower respiratory tract $(31 ; 34.4 \%)$, including nosocomial pneumonia in 24 patients $(77.4 \%)$ and nosocomial tracheobronchitis in 7 patients (22.6\%); sepsis $(7 ; 7,8 \%)$; intrabdominal infections (6; 6.7\%); infections of the urinary tract (1; $1.1 \%)$, and infective endocarditis $(1 ; 1.1 \%)$. The frequency of infectious complications in patients with different types of wound contamination is shown in Table 6.

PAP was administered to the majority of patients with clean (91.3\%) and clean-contaminated (91.6\%) wounds. The frequency of infectious complications in such patients was $14.1 \%$ and $19.5 \%$, respectively (Table 6). All patients with contaminated wounds underwent PAP; the frequency of infectious complications in this group was $27.1 \%(n=19)$. There were no reliable records about the administration of AA before surgery (usual timing is 30-60 min before the operation) to the patients with infected wounds although those patients did receive AA in the postoperative period $(61 ; 54.5 \%)$. In these patients the frequency of infectious complications was significantly higher than in the patients who did not receive PAP $(11 ; 18.03 \%)$ than in the patients who received adequate PAP in compliance with clinical guidelines $(6 ; 11.8 \%)$. Re-operations were necessary in $86(14.9 \%)$ cases, of which $32(37.2 \%)$ were associated with infectious complications and the rest 54 (62.8\%) were not.

Additionally, we have analyzed the associations between a few different factors, such as the bad choice of PAP, patients' clinical and demographic characteristics (age, sex, diagnosis, renal function, type of surgery, wound contamination, blood loss), the frequency of infectious complications, a need for a re-operation, the length of hospital stay, the length of stay in the intensive care unit, bacterial growth, and mortality (Table 7).
Statistically significant were the associations between the bad choice of PAP and mortality $(p=0.002)$, between prolonged PAP /inappropriate dosing and the length of stay in intensive care $(p=0.003$ and $p<0.005$, respectively). Inappropriate doses were shown to increase the risk of reoperations associated with post-op infection ( $p=0.001)$.

Importantly, elevated creatinine levels measured $24 \mathrm{~h}$ after the surgical intervention are a marker of renal function and demonstrate strong associations with the frequency of infectious complications $(p=0.006)$, the length of stay in intensive care $(p=0.049)$, the length of stay in hospital $(p=0.001)$, and mortality $(p=0.003)$.

\section{DISCUSSION}

The rational choice of PAP is one of the major tools for regulating the spread of nosocomial infections in surgical patients. PAP aims at reducing the risk of postoperative complications, the length of stay in intensive care and hospital in general, and mortality from septic or suppurative complications. Surgeons, anesthesiologists, clinical pharmacologists, epidemiologists and hospital administration should be encouraged to actively participate in the studies of compliance with international clinical standards for PAP.

Our study demonstrates that in $52.4 \%$ cases PAP regimens are consistent with international and national clinical guidelines. Failure to comply with clinical guidelines was observed in $47.6 \%$ cases when the choice of antibiotics was not rational, the regimens were extended beyond necessity $(85.4 \%)$ and the administered doses were inappropriate (66.4\%).

Our findings are consistent with those of Khan et al. [11], Vessal et al. [12] and El Hassan et al. [13] who also discovered the lack of compliance with the clinical guidelines for PAP in surgical patients; in those research works compliance varied

Table 4. Frequency of adverse reactions depending on PAP duration

\begin{tabular}{|c|c|c|}
\hline \multirow{2}{*}{ PAP duration } & \multicolumn{2}{|c|}{ AR } \\
\hline & абс. & $\%$ \\
\hline Administration of a single AA dose before surgery & 0 & - \\
\hline PAP extended to $24 \mathrm{~h}$ & 0 & - \\
\hline PAP extended to $48 \mathrm{~h}$ & 5 & 21.7 \\
\hline $3-4$ days & 3 & 13.0 \\
\hline $5-7$ days & 3 & 13.0 \\
\hline $8-10$ days & 5 & 21.7 \\
\hline $11-14$ days & 7 & 30.4 \\
\hline Total & 23 & 100.0 \\
\hline
\end{tabular}

Table 5. Associations between clinical and laboratory parameters and the risk of adverse reactions

\begin{tabular}{|l|c|c|}
\hline \multirow{2}{*}{\multicolumn{1}{|c|}{ Parameter }} & \multicolumn{2}{c}{ Adverse reactions } \\
\cline { 2 - 3 } & \multicolumn{2}{c}{$\begin{array}{c}\mathrm{p} 1 \\
\text { (Kolmogorov-Smirnov test) }\end{array}$} \\
\hline Age & 0.025 & $\mathrm{p}=0.308$ \\
\hline Allergies & $<15$ & $\mathrm{p}>1$ \\
\hline Duration of mechanical ventilation & $<0.0001$ \\
\hline Length of stay in intensive care & $<0.0001$ \\
\hline Length of hospital stay & $<0.0001$ \\
\hline Death & $<0.0001$ \\
\hline Postoperative non-infectious complications & $<0.0001$ \\
\hline Postoperative creatinine levels and clearance rate & $<0.0001$ \\
\hline Infectious complications & $\mathrm{p}=0.165$ \\
\hline
\end{tabular}


from $1.7 \%$ to $82 \%$. The majority of those studies were focused on the timing of preoperative prophylaxis.

According to Gouvêa et al., who have analyzed a few research works on the issue, PAP regimens are observed in $70.3 \%$ to $95 \%$ cases, the rational choice of PAP varies between $22 \%$ and $95 \%$, bad - between $2.3 \%$ and $100 \%$, wrong timing occurs in $73 \%$ to $100 \%$ cases, and total compliance with clinical standards for PAP - in 5.8\%-91.4\% cases [14].

A retrospective study by Prospero et al. has demonstrated that over the course of 6 years covered by the study PAP standards were observed in 58\% cases. The frequency of postoperative infectious complications was mostly affected by the length of surgery (OR 1.68; 95\% Cl: 1.56-1.82) and emergency (OR 2.16; 95\% Cl: 1.96-2.37). The authors note that in spite of poor adherence to PAP guidelines in general, the group where PAP protocols were observed had a low frequency of infectious complications [15].

To encourage medical personnel to adhere to PAP standards and improve clinical care, $\mathrm{WHO}$ experts recommend the use of checklists in the perioperative period [16].

In their works, some researchers focus on the choice of antibiotics used for PAP. According to our data, third generation cephalosporins, including those against Pseudomonas, are extensively used for perioperative prophylaxis. International studies by Lautenbach et al. [17] and Rodríguez-Baño et al. [18] demonstrate a high correlation between the use of 3rd generation cephalosporins and the spread of strains producing broad-spectrum $\beta$-lactamases. Our microbiological monitoring ( $n=84$ ) indirectly confirms a high incidence of such strains isolated from patients' samples (22; 26.2\%). There is a concern about the emergence of strains resistant to carbapenems Carb+ $(23 ; 27.4 \%)$ because the choice of AA for treating infectious complications caused by such strains is very limited.

In our study, adverse reactions were registered in 23 patients (3.99\%). There was a relatively high incidence of antibioticassociated colitis in patients receiving cephalosporins (9; 1.6\%) and episodes of psychomotor agitation in elderly patients receiving cephalosporins in combination with metronidazole
(6; 1.04\%). According to one of the epidemiological studies, antibiotic-associated diarrhea develops in $8 \%$ of inpatients, $1-3 \%$ of them have a fulminating course. The researchers conclude that apart from antibiotics, among the risk factors contributing to this condition are anticholinergics and medications inhibiting intestinal motility [19].

Grill et al. report a high incidence of neurological disorders following administration of fluoroquinolones to surgical patients. Among the conditions observed are episodes of psychomotor agitation, seizures, myoclonus, delirium, dysarthria, and ataxia. Severe neurologic responses are particularly frequent in elderly patients and patients with a history of neurological disorders. The researchers note that such adverse reactions are equally frequent for all types of fluoroquinolones [20].

The increased risk of adverse reactions following prolonged PAP supports the importance of adherence to clinical protocols. Our correlation analysis shows that adverse reactions correlate with the length of hospital stay $(r=0.291, p<0.0001)$, the length of stay in the intensive care unit $(r=0.374 ; p<0.0001)$, mortality $(r=0,269 ; p<0,0001)$, and the duration of mechanical ventilation $(r=0.249 ; p<0.0001)$.

Importantly, in patients receiving antibiotics the frequency of adverse reactions correlates with creatinine levels and creatinine clearance rates $(p<0.0001)$, which are used as markers of renal damage. The study [21, 22] has demonstrated that deteriorating renal function affects pharmacokinetics of antibiotics and increases the risk of adverse reactions to the point of life threatening. These data need to be prospectively studied in more detail.

\section{CONCLUSIONS}

Compliance with the guidelines for perioperative prophylaxis in the clinical setting remains poor.

Our study has revealed associations between the inadequate choice of antibiotics and mortality, prolonged PAP and the length of patient's stay in intensive care, inadequate dosing and the frequency of re-operations associated with post-op

Table 6. Frequency and type of infectious complications in patients with different types of wound contamination undergoing perioperative prophylaxis

\begin{tabular}{|l|c|c|c|c|}
\hline \multirow{2}{*}{$\begin{array}{c}\text { Infectious complications } \\
\mathrm{n}=90(15,6 \%)\end{array}$} & \multicolumn{4}{c|}{ Wound contamination, $\mathrm{n}(\%)$} \\
\cline { 2 - 5 } & $\begin{array}{c}\text { clean } \\
\mathrm{n}=310\end{array}$ & $\begin{array}{c}\text { clean-contaminated } \\
\mathrm{n}=84\end{array}$ & $\begin{array}{c}\text { contaminated } \\
\mathrm{n}=70\end{array}$ & $\begin{array}{c}\text { infected } \\
\mathrm{n}=112\end{array}$ \\
\hline SSI & $15(5.3)$ & $6(7.8)$ & $12(7.1)$ & $4(7.8)$ \\
\hline Nosocomial pneumonia & $15(5.3)$ & $3(3.9)$ & $4(5.7)$ & 0 \\
\hline Sepsis & $5(1.8)$ & $1(1.3)$ & 0 & 0 \\
\hline Other ${ }^{*}$ & $5(1.8)$ & $5(6.5)$ & $18(27.1)$ & $2(3.9)$ \\
\hline Total & $40(14.1)$ & $15(19.5)$ & $70(100)$ & $6(11.8)$ \\
\hline PAP administered & $283(91.3)$ & $77(91.6)$ & & $51(45.7)$ \\
\hline
\end{tabular}

Note: * — infective endocarditis, urinary tract infection, Hnosocomial tracheobronchitis, intraabdominal infection

Table 7. Impact of inadequate PAP regimens on hospital statistics

\begin{tabular}{|c|c|c|c|c|c|c|}
\hline \multirow[b]{2}{*}{ Inadequate PAP } & \multicolumn{6}{|c|}{ p (Mann-Whitney U) } \\
\hline & $\begin{array}{l}\text { Infectious } \\
\text { complications }\end{array}$ & $\begin{array}{l}\text { Length of stay in } \\
\text { intensive care }\end{array}$ & $\begin{array}{l}\text { Length of } \\
\text { hospital stay }\end{array}$ & $\begin{array}{c}\text { Re-operations } \\
\text { associated with post- } \\
\text { op infection }\end{array}$ & $\begin{array}{c}\text { Presence of } \\
\text { multidrug resistant } \\
\text { bacteria in patients' } \\
\text { samples }\end{array}$ & Death \\
\hline Prolonged PAP & $>1$ & 0.003 & 0.530 & 0.934 & 0.290 & 0.465 \\
\hline Inappropriate dosing & 0.603 & $<0.005$ & 0.500 & 0.001 & 0.016 & 0.980 \\
\hline $\begin{array}{l}\text { Elevated creatinine levels } 24 \mathrm{~h} \\
\text { after surgery }\end{array}$ & 0.006 & 0.049 & 0.001 & 0.567 & 0.899 & 0.003 \\
\hline All regimens & 0.900 & 0.116 & 0.206 & 0.103 & 0.610 & 0.002 \\
\hline
\end{tabular}


infections, as well as the length of stay in the intensive care unit.

Adverse reactions are a risk factor for extended mechanical ventilation and extended stay in the intensive care unit or hospital in general.

\section{References}

1. Aslanov BI, Zueva LP, Kolosovskaya EN, Lyubimova AV, Khoroshilov VYu, Dolgiy AA, et al. Printsipy organizatsil perioperatsionnoy antibiotikoprofilaktiki $v$ uchrezhdeniyakh zdravookhraneniya. Federal'nye klinicheskie rekomendatsii. Moscow; 2014. 42 p. Russian.

2. Gu Y, Kaku M. How can we fight against antimicrobial-resistant bacteria in the World Health Organization Western Pacific Region? Western Pac Surveill Response J. 2012 Jul 30; 3 (3): 40-2.

3. Spellberg B, Gilbert DN. The future of antibiotics and resistance: a tribute to a career of leadership by John Bartlett. Clin Infect Dis. 2014 Sep 15; 59 Suppl 2: S71-5.

4. Michael CA, Dominey-Howes D, Labbate M. The antimicrobial resistance crisis: causes, consequences, and management. Front Public Health. 2014 Sep 16; 2: 145

5. Bratzler DW, Dellinger EP, Olsen KM, Perl TM, Auwaerter PG Bolon MK, et al. Clinical practice guidelines for antimicrobial prophylaxis in surgery. Am J Health Syst Pharm. 2013 Feb 1; 70 (3): 195-283.

6. Harbarth S, Samore MH, Lichtenberg D, Carmeli Y. Prolonged antibiotic prophylaxis after cardiovascular surgery and its effect on surgical site infections and antimicrobial resistance. Circulation. 2000 Jun 27; 101 (25): 2916-21.

7. Kachroo S, Dao T, Zabaneh F, Reiter M, Larocco MT, Gentry LO, et al. Tolerance of vancomycin for surgical prophylaxis in patients undergoing cardiac surgery and incidence of vancomycinresistant enterococcus colonization. Ann Pharmacother. 2006 Mar; 40 (3): 381-5

8. Yakovlev SV, Zhuravleva MV, Protsenko DN, Beloborodov VB, Briko NI, Brusina EB, et al. [Antibiotic stewardship program for inpatient care. Clinical guidelines for Moscow hospitals]. Consilium Medicum. 2017; 19 (7.1. Surgery): 15-51. Russian.

9. Rasporyazhenie Pravitel'stva RF ot 25 sentyabrya $2017 \mathrm{~g}$ № 2045-r "O Strategii preduprezhdeniya rasprostraneniya antimikrobnoy rezistentnosti v RF na period do 2030 g.». Order of the Government of the Russian Federation. Russian.

10. ASHP therapeutic guidelines on antimicrobial prophylaxis in surgery. American Society of Health-System Pharmacists. Am J Health Syst Pharm. 1999 Sep 15; 56 (18): 1839-88.

11. Khan AKA, Mirsh PV, Rashed MR, Banu G. A study on the usage pattern of antimicrobial agents for the prevention of surgical site infections (SSIs) in a tertiary care teaching hospital. J Clin Diagn Res. 2013 Apr; 7 (4): 671-4

12. Vessal G, Namazi S, Davarpanah MA, Foroughinia F. Evaluation
Considering the reliable association between creatinine levels and the risk of infectious complications and death, we believe that renal function tests has a high prognostic value, which can be elucidated by further prospective studies of patients receiving PAP. of prophylactic antibiotic administration at the surgical ward of a major referral hospital, Islamic Republic of Iran. East Mediterr Health J. 2011 Aug; 17 (8): 663-8.

13. El Hassan M, Elnour AA, Farah FH, Shehab A, Al Kalbani NM, Asim S, et al. Clinical pharmacists' review of surgical antimicrobial prophylaxis in a tertiary hospital in Abu Dhabi. Int J Clin Pharm. 2015 Feb; 37 (1): 18-22.

14. Gouvêa M, Novaes Cde O, Pereira DM, Iglesias AC. Adherence to guidelines for surgical antibiotic prophylaxis: a review. Braz $J$ Infect Dis. 2015 Sep-Oct; 19 (5): 517-24.

15. Prospero E, Barbadoro P, Marigliano A, Martini E, D'Errico M. Perioperative antibiotic prophylaxis: improved compliance and impact on infection rates. Epidemiol Infect. 2011 Sep; 139 (9): 1326-31.

16. Implementation Manual WHO surgical safety checklist 2009. Safe surgery saves lives [file on the Internet]. Geneva, Switzerland: WHO; 2009 [cited 2017 Apr 10]: 20 p. Available from: http://apps. who.int/iris/bitstream/handle/10665/44186/9789241598590_ eng.pdf?sequence $=1$

17. Lautenbach E, Patel JB, Bilker WB, Edelstein PH, Fishman NO. Extended-spectrum beta-lactamase-producing Escherichia coli and Klebsiella pneumoniae: risk factors for infection and impact of resistance on outcomes. Clin Infect Dis. 2001 Apr 15; 32 (8): 1162-71.

18. Rodríguez-Baño J, Picón E, Gijón P, Hernández JR, Cisneros JM, Peña $C$, et al. Risk factors and prognosis of nosocomial bloodstream infections caused by extendedspectrum-beta-lactamase-producing Escherichia coli. J Clin Microbiol. 2010 May; 48 (5): 1726-31.

19. Greenstein AJ, Byrn JC, Zhang LP, Swedish KA, Jahn AE, Divino CM. Risk factors for the development of fulminant Clostridium difficile colitis. Surgery. 2008 May; 143 (5): 623-9.

20. Grill MF, Maganti RK. Neurotoxic effects associated with antibiotic use: management considerations. Br J Clin Pharmacol. 2011 Sep; 72 (3): 381-93.

21. Harris DG, McCrone MP, Koo G, Weltz AS, Chiu WC, Scalea TM, et al. Epidemiology and outcomes of acute kidney injury in critically ill surgical patients. J Crit Care. 2015 Feb; 30 (1): 102-6.

22. Blot S, Lipman J, Roberts DM, Roberts JA. The influence of acute kidney injury on antimicrobial dosing in critically ill patients: are dose reductions always necessary? Diagn Microbiol Infect Dis. 2014 May; 79 (1): 77-84.

\section{Литература}

1. Асланов Б. И., Зуева Л. П., Колосовская Е. Н., Любимова А. В., Хорошилов В. Ю., Долгий А. А. и др. Принципы организации периоперационной антибиотикопрофилактики в учреждениях здравоохранения. Федеральные клинические рекомендации. M.; 2014. 42 c.

2. Gu Y, Kaku M. How can we fight against antimicrobial-resistant bacteria in the World Health Organization Western Pacific Region? Western Pac Surveill Response J. 2012 Jul 30; 3 (3): 40-2.

3. Spellberg B, Gilbert DN. The future of antibiotics and resistance: a tribute to a career of leadership by John Bartlett. Clin Infect Dis. 2014 Sep 15; 59 Suppl 2: 71-5

4. Michael CA, Dominey-Howes D, Labbate M. The antimicrobial resistance crisis: causes, consequences, and management. Front
Public Health. 2014 Sep 16; 2: 145.

5. Bratzler DW, Dellinger EP, Olsen KM, Perl TM, Auwaerter PG, Bolon MK, et al. Clinical practice guidelines for antimicrobial prophylaxis in surgery. Am J Health Syst Pharm. 2013 Feb 1; 70 (3): 195-283.

6. Harbarth S, Samore MH, Lichtenberg D, Carmeli Y, Prolonged antibiotic prophylaxis after cardiovascular surgery and its effect on surgical site infections and antimicrobial resistance. Circulation. 2000 Jun 27; 101 (25): 2916-21.

7. Kachroo S, Dao T, Zabaneh F, Reiter M, Larocco MT, Gentry LO, et al. Tolerance of vancomycin for surgical prophylaxis in patients undergoing cardiac surgery and incidence of vancomycinresistant enterococcus colonization. Ann Pharmacother. 2006 
Mar; 40 (3): 381-5.

8. Яковлев С. В., Журавлева М. В, Проценко Д. Н., Белобородов В. Б., Брико Н. И., Брусина Е. Б. и др. Программа СКАТ (Стратегия Контроля Антимикробной Терапии) при оказании стационарной медицинской помощи. Методические рекомендации для лечебно-профилактических учреждений Москвы. Consilium Medicum. Хирургия. (Прил.) 2017; 7.1: 15-51.

9. Распоряжение Правительства РФ от 25 сентября 2017 г. № 2045-р «О Стратегии предупреждения распространения антимикробной резистентности в РФ на период до 2030 г.»

10. ASHP therapeutic guidelines on antimicrobial prophylaxis in surgery. American Society of Health-System Pharmacists. Am J Health Syst Pharm. 1999 Sep 15; 56 (18): 1839-88.

11. Khan AKA, Mirsh PV, Rashed MR, Banu G. A study on the usage pattern of antimicrobial agents for the prevention of surgical site infections (SSIs) in a tertiary care teaching hospital. J Clin Diagn Res. 2013 Apr; 7 (4): 671-4.

12. Vessal G, Namazi S, Davarpanah MA, Foroughinia F. Evaluation of prophylactic antibiotic administration at the surgical ward of a major referral hospital, Islamic Republic of Iran. East Mediterr Health J. 2011 Aug; 17 (8): 663-8.

13. El Hassan M, Elnour AA, Farah FH, Shehab A, Al Kalbani NM, Asim S, et al. Clinical pharmacists' review of surgical antimicrobial prophylaxis in a tertiary hospital in Abu Dhabi. Int J Clin Pharm. 2015 Feb; 37 (1): 18-22.

14. Gouvêa M, Novaes Cde O, Pereira DM, Iglesias AC. Adherence to guidelines for surgical antibiotic prophylaxis: a review. Braz $\mathrm{J}$ Infect Dis. 2015 Sep-Oct; 19 (5): 517-24.

15. Prospero E, Barbadoro P, Marigliano A, Martini E, D'Errico M. Perioperative antibiotic prophylaxis: improved compliance and impact on infection rates. Epidemiol Infect. 2011 Sep; 139 (9): 1326-31.
16. Практическое руководство по использованию контрольного перечня ВОЗ по хирургической безопасности, 2009 г. Безопасная хирургия спасает жизни [файл из интернета]. Женева, Швейцария: ВОЗ; 2009 [дата обращения: 15 января 2018 г.]: 20 с. Доступно по: http://apps.who.int/iris/bitstream/ha ndle/10665/44186/9789244598597_rus.pdf/;jsessionid=4FAB6 A191F92C8A475119413079895C3? sequence $=7$

17. Lautenbach E, Patel JB, Bilker WB, Edelstein PH, Fishman NO. Extended-spectrum beta-lactamase-producing Escherichia coli and Klebsiella pneumoniae: risk factors for infection and impact of resistance on outcomes. Clin Infect Dis. 2001 Apr 15; 32 (8): 1162-71

18. Rodríguez-Baño J, Picón E, Gijón P, Hernández JR, Cisneros JM, Peña $C$, et al. Risk factors and prognosis of nosocomial bloodstream infections caused by extended-spectrum-betalactamase-producing Escherichia coli. J Clin Microbiol. 2010 May; 48 (5): 1726-31.

19. Greenstein AJ, Byrn JC, Zhang LP, Swedish KA, Jahn AE, Divino $\mathrm{CM}$. Risk factors for the development of fulminant Clostridium difficile colitis. Surgery. 2008 May; 143 (5): 623-9.

20. Grill MF, Maganti RK. Neurotoxic effects associated with antibiotic use: management considerations. Br J Clin Pharmacol. 2011 Sep; 72 (3): 381-93.

21. Harris DG, McCrone MP, Koo G, Weltz AS, Chiu WC, Scalea TM, et al. Epidemiology and outcomes of acute kidney injury in critically ill surgical patients. J Crit Care. 2015 Feb; 30 (1): 102-6.

22. Blot S, Lipman J, Roberts DM, Roberts JA. The influence of acute kidney injury on antimicrobial dosing in critically ill patients: are dose reductions always necessary? Diagn Microbiol Infect Dis. 2014 May; 79 (1): 77-84 